\title{
A BRIEF HISTORY OF KARABAKH AND THE ARMENIAN- AZERBAIJANI RELATIONS: BEFORE THE FIRST ARMENIAN-MUSLIM CLASH (1905-1906)
}

\author{
Asim Jannatoglu Jannatov*
}

\begin{abstract}
The article deals with a brief history of Karabakh and the ArmenianAzerbaijani conflict between the two republics of South Caucasus - Azerbaijan and Armenia, including the primary aim of defining the ethno-political processes and historical occurrences as emerging the Armenian problem in the Azerbaijani territory of Nogorno-Karabakh (Azerbaijani: Dağlıq Qarabağ). The aim of this writing is to learn how and why this ethnic, religious and political conflict appeared between Armenian and local population of Nogorno-Karabakh. Of course, all the remarkable factors in this article let us prove that the initial indigenous people of Karabakh were the Azerbaijani Turks. In fact, Karabakh historically and legally is an integral territory of the Republic of Azerbaijan recognized by the international community.
\end{abstract}

Keywords: Karabakh, Azerbaijan, Armenian, Historical Background, ArsakArtsak, Arran Karabakh.

\section{KARABAĞ'IN KISA TARIHI VE ERMENI-AZERI ILIŞKILERi: ILK ERMENI-MÜSLÜMAN ÇATIŞMASINDAN ÖNCE (1905-1906)}

\section{Özet}

Makale Karabağ'ın kısa tarihi ve Güney Kafkasya'nın iki cumhuriyeti olan Azerbaycan ve Ermenistan arasındaki Ermeni-Azeri ilişkilerini irdelemektedir. Burada başlıca hedef Dağıık Karabağ'ın Azerilere ait topraklarındaki Ermeni meselesinin ortaya çıkışı olarak etnik-siyasi süreci ve tarihî olayları tanımlamaktır. Bu makalede amaç Ermenistan ile Dağlık Karabağ'ın yerel nüfusu arasında bu etnik, dini ve siyasi çatışmanın nasıl ve neden ortaya çıktığını öğrenmektir. Elbette, bu makaledeki bütün dikkate değer faktörler bize Karabağ'ın ilk yerli halkının Azeriler olduğunu göstermektedir. Aslında, tarihi ve yasal olarak Karabağ, Azerbaycan Cumhuriyeti'nin uluslar arası toplum tarafından kabul gören bir parçasıdır.

Keywords: Karabağ, Azerbaycan, Ermenistan, tarihsel arka plan, Arsak-Artsak, Arran Karabağ.

\footnotetext{
* Master's Student, Sapienza University of Rome, Political Sciences, Sociology and Communication Faculty, Department of Communication and Social Research.
} 


\section{Introduction}

This article traces the ethno-political history of Armenian-Azerbaijani conflict in the Azerbaijani territory of Karabakh which played a leading role in the Azerbaijani statehood due to its strategic position. Undoubtedly, it is extremely necessary to investigate any kind of researches' consequences to communicate its today with the past. First of all, we should refer the local Azerbaijani historian Mirza Jamal Javanshir Garabaghi (1773-1853) for defining the borders of Karabakh. In his book of "History of Karabakh" he noted: "Karabakh is bounded by Araz river to the south, Kur river to the east, Goran river to the north, Karabakh mountains to the west." ${ }^{11}$ The initial information about Karabakh goes first centuries BC. The crucial part of the paper plays a key component role in the clarification of this topic which confirms that Karabakh inhabited by dominant ethnic Turks and it is an integral part of historical Azerbaijani lands. It has been one of the main provinces of an Ancient Azerbaijani state - Caucasian Albania ( $4^{\text {th }}$ century BC - the beginning of the $8^{\text {th }}$ century $A D)$ which also included itself the territory of modern Azerbaijan, covered a vast area. In the earlier written sources, Karabakh was initially remembered under the name of Arsakh-Artsakh, enclosing today's Upper Karabakh and one piece of the Mil plain of the Republic of Azerbaijan. Karabakh has ever been in the spotlight in South Caucasus due to its strategic position and political necessity since the early Middle Ages. Of course, we can receive much more information about the origin, population, territories, state boundaries and internal-external condition of Caucasian Albania, including also Arsakh in the ancient written sources.

It is very necessary to use the consequences of archaeological, etymological and historical investigations in order to deal with the history of Karabakh. Based on the main concept, we focus on defining the origin of Karabakh and the first Armenian invasion to Azerbaijani lands in the first two parts of the article. In the next part, we would like to give an explanation to today's controversial region's necessity in the political context and the advantages of Oghuz-Seljuk Turks' migration that played a central role in strengthening the Turkic domination over the whole territory of Azerbaijan. In the last analytical part, we will summarize the

${ }^{1}$ Garabaghnameler, Mirza Jamal Javanshir Garabaghi, Qarabağnamə. /in Azerbaijani/ Garabaghname, (Baku, Şərq-Qərb, 2006), Chapter 1, p. 122.

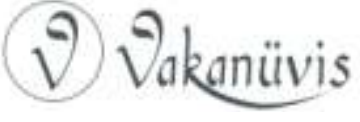


disadvantages of the khanate period existed in Azerbaijan, the Russian occupation and the first artificial Armenian resettlement in Karabakh by the Czarist Russia.

\section{Defining the Origin of Karabakh}

Karabakh was an integral western province of an Ancient Azerbaijani state - Caucasian Albania. So, it should be better for dealing with its history if we refer the local Albanian historian M. Dasxuranci's ${ }^{2}$ book of "History of the Caucasian Albanians". Most of Armenian historians try to fabricate its origin in order to represent it as a historical region of Armenia with their morbid claims in their in-depth. However, there were no Armenian elements on the territory of Caucasian Albania in the first centuries BC. In response to their pretension, we would like to show the realities in this area according to historical factors. In this case, there is a question to explain the meaning of Arsakh-Artsakh. What does its etymology mean?

As we mentioned, Karabakh (especially Nogorny Karabakh) was initially depicted under the name of Arsakh-Artsakh. The etymology of Arsakh is related to the name of ancient Turkic tribe Sakh, containing two words such as "ar" and "sakh" that means sakh man, brave sakh, encourages sakh ${ }^{3}$ and the etymology of Artsakh in old Turkic languages, derives "art" and "sakh" which means sakh mountainous territory. ${ }^{4}$ Sakh people as an important ethnic component have been one of the "26 Albanian tribes" 126 tribes coexisted in Caucasian Albania). The scholars and historians have their different attitude about the origin of this tribe. Some of them suppose to concern the Sakh tribes to the Iranian language group, while the others assume that they are originally Turks. Generally, settlement of these tribes in different Azerbaijani areas is related to the

\footnotetext{
${ }^{2}$ It is a general reference to get more details about the ancient Azerbaijani State of Caucasian Albania. The History of the Caucasian Albanians by Mouses Dasxuranci. Trans by C.J.F.Dowsett. (Bulletin of the school of Oriental and African Studies, University of London, 1962).

${ }^{3}$ M.Ismayıl, Azarbaycan xalqının yaranması. /in Azerbaijani/ The origin of Azerbaijani population/(Baku, Azərnəşr, 2007), p.13.

${ }^{4}$ Q.Qeybullayev, Azarbaycan türklarinin taşəkkülü tarixindən. /in Azerbaijani/ From the fromalising history of Azerbaijani Turks/ (Baku, Təhsil, 1994), p. 169.

${ }^{5}$ Strabo. Geography, (IV). Cambridge, MA, 1969.
}

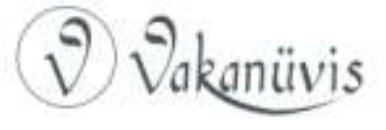


$7^{\text {th }}$ century BC. As a result of sustainability of archaeological researches, found out a great number of material evidences in different Azerbaijani territories where the Sakh tribes lived and all these scientifically confirm that Arsakh initially resided by the Sakhs from the Ancient Times. Three main factors such as making "kumis" (horse milk) and "tumbrel" covered felt (cutis) $)^{6}$ and "to put on a specific hat" are belong to this Turkic tribe and now kept solidly in Turkic-language communities. ${ }^{7}$ Moreover, the material evidences confirm the existence of different place names such as Arsakh or Artsakh, Sakasena, Sisakan, Shaki (today's north-western Azerbaijani city) and Sakh street (located in today's Nüsnüs village in the Ordubad Rayon of Nakhchivan, Azerbaijan) in Azerbaijani territory concerned to the Sakhs. Hence, all these factors let us say that they have originally become Turks and played a central role in the ethnogeny process of Azerbaijani population. In the first centuries AD, Arsakh was a western province of Azerbaijani state - Caucasian Albania inhabited by a few Turkic tribes such as the Albans, Qarqars, Utils, Huns, Khazars and Barsils. ${ }^{8}$

By the $8^{\text {th }}$ century in the written sources, Arsakh was described under the name of Akhvan as being a part of Arran ${ }^{9}$ (today's lowland areas between Kur and Araz rivers, Azerbaijan), including also itself a western neighbouring province - Girdiman ${ }^{10}$. The next Middle Ages' sources retained this region under the name of Arran Karabakh. As we see, this province gradually transformed from its initial name, Arsakh into Karabakh (Arsakh-Artsakh-Akhvan-Arran Karabakh-Karabakh). Of course, Karabakh is a Turkic word, most commonly translated as "Black Garden".

\footnotetext{
${ }^{6}$ M.Ismayıl, Azarbaycan xalqının yaranması. /in Azerbaijani/ The origin of Azerbaijani population/, (Baku, Azərnəşr, 2007), p.18.

${ }^{7}$ Q.Qeybullayev, Azarbaycan türklarinin taşəkkülü tarixindən. /in Azerbaijani/ From the fromalising history of Azerbaijani Turks/ (Baku, Təhsil, 1994), pp. 155156.

${ }^{8}$ Azərbaycan Tarixi Ensiklopediyasi. /in Azerbaijani/ Encyclopedia, Azerbaijani History, Cover 2, Chapter 2, (Baku, Təhsil, 2007), p.17.

${ }^{9}$ It is a general reference. The History of the Caucasian Albanians by Mouses

Dasxuranci. Trans by C.J.F.Dowsett. (Bulletin of the school of Oriental and African Studies, University of London, 1962).

${ }^{10}$ It is a general reference. Qafar Jabiyev, Girdiman tarixi. /in Azerbaijani/ History of Girdiman/ (Baku, Şərq-Qərb, 2010).
}

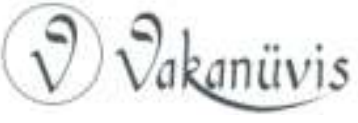


It may refer to the fertility of this region-even though the "Black" now seems as a symbol of death and misery. ${ }^{11}$ However, "Black" generally means "great" in a growing number of Turkic languages that was taken by great persons as a title who has a special action in a group or a community.

\section{First Armenian Invasion In Azerbaijani Lands}

All these arguments give us a basis to say that Arsakh-Artsakh has been a western province of Ancient Azerbaijani state - Caucasian Albania, and Azerbaijani Turks are the indigenous population of this region. In this case, such a question arises. When did the Armenians move to the historical Azerbaijani lands?!

First of all, we would like to highlight that the Armenians call themselves "Haik". The Armenians is represented as a branch of the IndoEuropean language family. In any case, the Armenian historians simultaneously try to substantiate their affinity with the "Urartians". However, the Hurrian-Urartians comes from the Asian linguistic sphere and there is no linguistic or ethnic connection between them. ${ }^{12}$ From this point of view, these two claims are absolutely opposite concepts to each other. In general, arrival of the Armenians in Azerbaijani territories occurred in the first centuries BC. During that period Albanian area played a very decisive role in the political competition existed between the Sassanid (Persian) and Roman Empires, due to its strategic position in South Caucasus. The Armenians succeeded to create their own small state on the shores of the Lake Van in Minor Asia nearly in the second century BC. Armenian state strengthened and invaded some neighbouring territories, including also some regions of Albania in the $80 \mathrm{~s}$ of the first century BC. However, this condition lasted approximately for ten years. Armenian state then left occupied territories and came back to surroundings of the Lake Van, defeated by the Roman troops in $66 \mathrm{BC}$. Armenian state usually used to provocate Christianity among the Albanian community, sending many priests of Armenian-Gregorian church to release people under their influence. In other words, they implemented their ideological propaganda before and after the defeat of 66 BC. As a

\footnotetext{
${ }^{11}$ THOMAS DE WAAL, BLACK GARDEN. Armenia and Azerbaijan through Peace and War. (New York: New York University Press, 2003), p. 23.

${ }^{12}$ Erich Feigl, Armenian Mythomania, 2007, p.12.
}

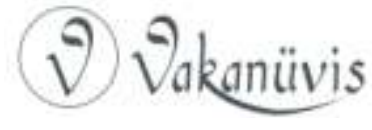


result of their successful action, some groups of the Albans adopted the Gregorian brief of Christianity next following centuries. However, the subsequent historical process like creation of Islamic religion and enhancing the Islamicization process in Azerbaijani area effectively ceased to spread Christianity in Karabakh, Albania. This situation impeded the Armenian state's invasion purpose against the territorial integrity of Caucasian Albania.

\section{The Political Necessity of Karabakh for Azerbaijan}

We receive the information about the history of Karabakh most commonly in the Arabic written sources due to the dependency of Azerbaijan on the Arabic Caliphate since the beginning of the $8^{\text {th }}$ century. In 705, Arab Caliphate completed the occupation process of Azerbaijan, invading Caucasian Albania, including also Karabakh which had a special importance according to its strategic position for a counter-attack around the mountains... Consequently, Azerbaijani population began to adopt Islam, as they shared some familiar social and cultural dimensions with Islamic culture. This is why Islam spread very fast among the people, and it has turned the dominant religion in Azerbaijan since that historical period. Most of Azerbaijanis people became the Muslims, while the others kept Christianity in the northern mountainous provinces, especially in Karabakh. Some of the Christian Albans gradually lost their national identity and mixed with the Armenians under the influence of the Armenian - Gregorian church.

During the second half of the $9^{\text {th }}$ century, Arabic occupation terminated and the statehood was restored in Azerbaijan. A new power was established over the whole Azerbaijani territory initially in the case of centralized Azerbaijani feudal state - Saciler (879-941), and then that replaced with one another Azerbaijani feudal state - Salarilar (941-981). Among the feudal states Azerbaijan Shaddadilar state (951-1174) also played an essential role that covered today's western part of Azerbaijan. Of course, Karabakh was one of the main substantial provinces of these three states in accordance with its geostrategic position, located on the border with their western neighbours.

In such a time, the consistent migration of Oghuz-Seljuk Turks started to the Middle East and South Caucasus that served the expansionist policy of Great Seljuk Empire (1037-1094). Hence, the large number of Turkic

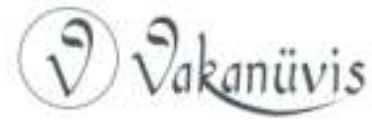


dynasties increased in Azerbaijan and Anatolia by the arrival of Oguz and other Turkic nomads and semi-nomads from Central Asia. ${ }^{13}$ During the period of the $11^{\text {th }}-12^{\text {th }}$ centuries, the mass flow of the Oghuz-Seljuk tribes to Azerbaijan promoted the dominant position of the ethnic Turks in the whole Azerbaijani territory, including also Karabakh. However, this case was extremely undesirable for the Armenian authorities that created obstacles in front of them to implement their future plans in Azerbaijani areas. In spite of all, they tried to invade several regions of Azerbaijani Shaddadilar state with military support of Byzantine Empire... However, the united Byzantine-Armenian troops were defeated by the united Seljuk-Azerbaijani armed bands in $1037 .{ }^{14}$ The strengthening of the domination of Seljuk Turks in Eastern Anatolia has terminated the Byzantine threat over the Azerbaijani territories since the $11^{\text {th }}$ century, and this situation deprived the Armenians to implement their insidious plans in Karabakh for a long term.

In the following historical periods, Karabakh played an important role as usual in the political life of Azerbaijani states - Atabeyler (1136-1225), Kara Koyunlu (1410-1467) and Ak Koyunlu (1468-1501) due to its strategic position as in the past. One of the principal matters is to study the emergence of melikliks (principalities) in Karabakh referring to historical circumstances in the $15^{\text {th }}$ century. "In the fifteenth century Alban dynasty Hasan Celal (Celaliler) took over Melik title (Azerbaijani: "melik" means owner, judge. This title was given either Muslim or Armenian feudals) from the Qara Qoyunlu Cahan shah... Celaliler dynasty then separated into five Alban feudal principalities - meliklik such as Gulustan, Chileberd, Khachin, Varand and Dizakh". ${ }^{15}$ In any case, Armenian historians intend to represent these melikliks as Armenian dynasties trying to fabricate their origin. According to their claims, they have become Gregorian Armenians. In contrast, we should say that all these melikliks were originally Christian Albans before losing their Alban origin under the influence of Armenian Gregorian church.

13 Peter B. Golden, The Turkic People and Caucasia. (Conference on "NATIONALISM AND SOCIAL CHANGE IN TRANSCAUCASIA" Number 92, 1980), pp. 24-25.

${ }^{14}$ S.Aliyarli, Azarbaycan Tarixi. /in Azerbaijani/ History of Azerbaijan, (Baku, Çıraq, 2009), pp. 211-212.

${ }^{15}$ Karabakh: Questions and Facts, (Baku, 2005), pp. 12, 20.

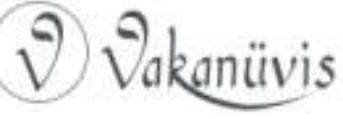


During the period of centralized Safavid Empire (1501-1736) the local self-administration structure was abolished and established a new administrative-territorial unit that is called beylerbeylik. ${ }^{16}$ With regard to this system, Karabakh was one of the 13 beylerbeyliks, containing 7 sanjaks and 36 nahiyes (Azerbaijani: beylerbeylik, sanjak and nahiye were territorial units during the Middle Ages). We would like also to say that under the name of Karabakh is considered a huge area between the rivers of Kur and Araz in the Azerbaijani territory.

After the collapse of Safavid Empire, a tense and very complicated political situation dominated in Azerbaijan. Then Safavid dynasty was replaced with Nadir shah dynasty, and, in fact, he tried to utilize Alban melikliks in his own political aim. So the self-administrative structure was revived in the mountainous part of Karabakh... After death of Nadir shah in 1747 the activity of these melikliks significantly weakened. However, some foreign and domestic forces started to use them against the Karabakh khanate in the khanate period.

\section{Azerbaijani Khanate Period, Russian Occupation and First Artificial Armenian Resettlement in Karabakh by Russia}

The internal condition and political situation were extremely unstable and complicated in Azerbaijan after the event of 1747. Azerbaijan split into independent political units in the mid of $18^{\text {th }}$ century when Nadir shah was assassinated by domestic forces in Karabakh which we call them khanate (Azerbaijani: "khanate" means a kingdom that may be seen as a city state in the case of Azerbaijan). In this suitable circumstance, arose a number of stronger khanates in the Azerbaijani territory. Karabakh also declared its self-determination by the founder of Karabakh khanate Panah khan and it became an urgent one among the others.

Eventually, this undesirable situation in Azerbaijan created a special condition to attack into Azerbaijani territories by neighbouring countries such as Russia and Iran. So, the khanate was confronted with a serious threat by its northern neighbouring country. As a result, Ibrahim khan agreed to adopt the annexation to Czarist Russia suggested by Russian

\footnotetext{
${ }^{16}$ Tarixe-alamaraye-Abbasi by Iskender bey Munshi Turkman, Trans into Azerbaijani by S. Fazil. (Baku, 2010), pp. 164-165.
} 
representative - General P. D. Sisianov. The Kurekchai treaty ${ }^{17}$, signed in May 14, 1804, affirmed the annexation of Karabakh by Russian Empire which contained 11 paragraphs. After concluding the contract, Karabakh lost its foreign politics but kept its domestic sovereignty. In fact, Karabakh khanate was annexed to Russian Empire as an Azerbaijani territory.

The rivalry to capture Azerbaijani lands and over the hegemony in South Caucasus and in the Caspian Sea led to start two military campaigns between Russia and Iran, which were concluded with the Treaties of Gulistan (October 12, 1813) and Turkmanchai (February 10, 1828). As a result of the latter which consisted of 16 paragraphs, the Russian Empire gained sovereignty over the northern part of Azerbaijan. Thus, the Turkmanchai treaty ${ }^{18}$ affected to change the ethnical scheme of Karabakh, especially the fifteenth paragraph was dedicated resettlement of thousands of Armenian families to South Caucasus from Iran. Three main Azerbaijani provinces - Karabakh, Nakhchivan and Iravan were in the target on the charge of contribution to Armenian families for their resettlement according to the Czarist Russia's migratory policy.

We can see the same clauses relating Armenian migration in the case of one another treaty. So the 1828-1829 Russian-Ottoman war resulted in defeating the Ottoman troops by Russian Empire, and the Ottomans were forced to sign a contract in Edirne ${ }^{19}$ that included also Armenian resettlement to Azerbaijani territories from different provinces of the Ottoman Empire. After this case, Karabakh again became the victim of the Russian authorities' migratory policy.

According to Russian authorities' aspiration, Armenian resettlement started from Iran and Minor Asia to historical Azerbaijani lands Karabakh, Nakhchivan and Iravan since 20s-30s of the $19^{\text {th }}$ century. As a

17 A.P. Berzhe (Ed.), Акты собранные Кавказской Археографической Комиссии, T. II. Под ред. /in Russian/ Records collected by the Caucasian Archaeological Commission, (Тифлис, 1868), pр. 702-705.

${ }^{18}$ Сборник трактатов, конвеций и других актов, заключенных Россией $c$ Европейскими и Азиатскими державами, a также $и$ c СевероАмериканскими Штатами. /in Russian/Collection of treatises, conventions and other acts concluded by Russia with the European and Asian powers, as well as with the North American states., (СПБ, 1845), pp.139-149.

${ }^{19}$ Şerafettin Turan, "1828 Edirne Antlaşması". /in Turkish/ "1828 Edirne Treaty", (Atatürk Üniversitesi Dil Tarih Coğrafya Fakültesi, Ankara 1995).

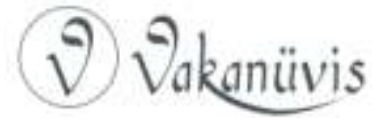


result of the migratory wave, thousands of Armenian families were resettled in these regions, and this situation created ethnic diversity in Karabakh. All these resettlement processes were implemented by Russian ambassador in Iran A. C. Griboedov, and Russian general Paskevich, including the sustainable contribution of priests of the ArmenianGregorian church. Foremost, Armenian families were provided with financial support and lands by evacuating local Azerbaijani villages. Indeed, Azerbaijani population were forced to change their homeland leaving the permanent residence under the Czarist Russia's pressure. These migration patterns influenced to alter the population rate in Karabakh. According to the ethno-demographic indicators in this region, 91 percent of its population was the Azerbaijanis and 8 percent was the Armenians in 1823. However, the artificial resettlement of Armenian families increased this indicator from $8 \%$ to $35 \%$, and the number of Azerbaijani population reduced from $91 \%$ to $65 \%$ in 1832 in Karabakh. ${ }^{20}$

These types of resettlement policies accelerated during a few decades, and all of them were implemented by the Russian Czarism's administrative organizations in South Caucasus that served its policy of ethnic cleaning in this region. However, Albanian Christian church was abolished by the Russian government's decision in 1836. After this case, Armenian historians tried to fabricate the historical reality changing the written texts from Alban script to Armenian in many Christian churches of different Azerbaijani provinces, even in Karabakh. All these events entailed to alter the ethno-political situation in this region and Christian Albans absolutely lost their national identity, and mixed with Armenians. Armenian leadership then started to work out some plans to deteriorate the Armenian-Azerbaijani relations which were aiming at artificially establishing Great Armenia initially on the Azerbaijani lands. In any case, the Armenians were supported with socio-economic and military aid by Czarist Russia. Finally, they succeeded in intensifying the tension between the Armenians and the Azerbaijanis and it turned a conflict by starting Armenian aggression against the Azerbaijanis at the beginning of the twentieth century which is ongoing at present.

\footnotetext{
${ }^{20}$ S.Aliyarli, Azarbaycan Tarixi. /in Azerbaijani/ History of Azerbaijan, (Baku, Çıraq, 2009), pp. 672-674.
}

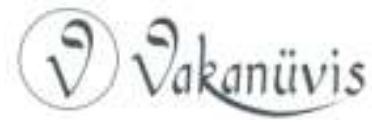




\section{Conclusion}

As we see the political situation completely changed when the Czarist Russia took sovereignty on the status of South Caucasus, subordinating also Azerbaijan. After this case, the situation absolutely changed, and the Armenian-Russian relationship ties strengthened. In general, history of this relationship ties between them started with issuing a decree by Great Peter I, in 1724 which included resettlement of Armenians on the shores of the Caspian Sea in Azerbaijani area. Thus Russian authorities gave a prominence to the Armenian resettlement in order to create an ethnic support in this region for their future plans because of sharing the same religion. Consequently, this process has begun sustainably since 1828 , and continued in many decades. To conclude, all these processes effected to change the ethnical scheme of Karabakh. Christian Albans gradually mixed with the Armenians, and lost their national identity. So, all these acts took it from the Armenian-Muslim clash to today's continues Nogorny Karabakh conflict.

However, the Armenian historians are now trying to represent these Christian Albans as the local Armenian population of Karabakh as well as possible. Of course, this is an absolute idea that expired its morbid meaning. Finally, analyzing the realities we would like to say that the indigenous population of Karabakh are the Azerbaijani Turks, and Karabakh is an integral territory of the Republic of Azerbaijan. The fact is that Nagorno-Karabakh is recognized as Azerbaijani land by the United Nations' resolution. ${ }^{21}$

\section{Bibliography}

1993 UN Secretary Council Resolutions on Nagorno-Karabakh, http://2001-2009.state.gov/p/eur/rls/or/13508.htm

Aliyarli, S., Azarbaycan Tarixi, Baku, Çıraq, 2009.

Azərbaycan Tarixi Ensiklopediyası (2007), 2/2, Baku, Təhsil.

\footnotetext{
${ }^{21} 1993$ UN Secretary Council Resolutions on Nagorno-Karabakh, http://20012009.state.gov/p/eur/rls/or/13508.htm
} 
Berzhe, A. P. (Ed), Акты собранные Кавказской Археографической Комиссии, 2, Под ред, (Records collected by the Caucasian Archaeological Commission), Тифлис, 1868.

Dasxuranci, Mouses, "The History of the Caucasian Albanians", Trans. by: C.J.F.Dowsett, Bulletin of the School of Oriental and African Studies, University of London, London, 1962.

De Waal, Thomas, Black Garden: Armenia and Azerbaijan Through Peace and War, New York University Press, New York, 2003.

Feigl, Erich, Armenian Mythomania, Amalthea Signum, Wien, 2007.

Garabaghnameler, Mirza Jamal Javanshir Garabaghi, Qarabağnama, Baku, Şərq-Qərb, 2006.

Golden, Peter B., The Turkic People and Caucasia, Conference on "Nationalism and Social Change in Transcaucasia", Wilson Center, Kennan Institute for Advanced Russian Studies Washington DC, 1980.

Iskender bey Munshi Turkman, Tarixe-alamaraye-Abbasi, Trans. into Azerbaijani by S. Fazil, Baku, 2010.

Ismayıl, M., Azarbaycan Xalqının Yaranması, Baku, Azərnəşr, 2007.

Jabiyev, Qafar, Girdiman Tarixi, Baku, Şərq-Qərb, 2010.

Karabakh: Questions and Facts, Baku, 2005.

Qeybullayev, Q., Azərbaycan Türklərinin Taşəkkülü Tarixindən, Baku, Təhsil, 1994.

Strabo, Geography, 4, Cambridge, MA, 1969.

Turan, Şerafettin, "1828 Edirne Antlaşması", Ankara Üniversitesi Dil ve Tarih- Coğrafya Fakültesi Dergisi, 9/12, Ankara, 1995.

Сборник трактатов, конвеций и других актов, заключенных Россией с Европейскими и Азиатскими державами, а также и с Северо-Американскими Штатами, (Collection of treaties, conventions and other acts concluded by Russia with the European and Asian powers, as well as with the North American states), СПБ, 1845. 